\title{
Perfect Performance for export: shame, narcissism and contaminated ideals in Santos-Febres' Sirena Selena (2000)
}

\author{
María Celina Bortolotto \\ School of Humanities, Media and Creative Communications, Massey University, NZ \\ m.c.bortolotto@massey.ac.nz
}

\begin{abstract}
In her first novel, situated in "this soup of islands stewed in hunger and the desire to be someone else" (Sirena Selena 211), Santos-Febres explores the world of transvestites and young male prostitutes following the trajectory of a new star, bolero-singer and seductive diva "Sirena Selena," from the streets of San Juan, Puerto Rico, to rich audiences in the Dominican Republic. The novel shows feminine characters that resist shame and humiliation by narcissistically focusing on themselves as a means of survival, adhering each to different rigid ideals of femininity permeated by normative systems of value focusing on appearance, financial solvency or ambiguous desire. Their tactics are deployed against a background where the social geography of the islands appears hierarchically ordered with Haiti at the bottom, the Dominican Republic and Cuba in the middle, and Puerto Rico at the top. The novel alludes to the social/political/ economic hierarchies that organize migrations among islands in the Caribbean, always against the powerful backdrop of the United States. Sex tourism is recreated as a profitable industry that relaxes strict machista prejudices and allows for sexual experimentation of those who pay and some degree of social mobility of those whose bodies are for hire.
\end{abstract}

Keywords: Santos-Febres; Puerto Rican Literature; Queer; Sex tourism; Affect Theory

I'm much more interested in getting through your pores, all your parts, infecting you... -Mayra Santos-Febres

In her first novel, situated in "this soup of islands stewed in hunger and the desire to be someone else" (Sirena Selena 211), Santos-Febres explores the world of transvestites and young male prostitutes following the trajectory of a new star, bolero-singer and seductive diva "Sirena Selena," from the streets of San Juan, Puerto Rico, to rich audiences in the Dominican Republic. The novel shows feminine characters that resist shame and humiliation by narcissistically focusing on themselves as a means of survival, adhering each to different rigid ideals of femininity permeated by normative systems of value focusing on appearance, financial solvency or ambiguous desire. Their tactics are deployed against a background where the social geography of the islands appears hierarchically ordered with Haiti at the bottom, the Dominican Republic and Cuba in the middle, and Puerto Rico at the top. The novel alludes to the social/political/economic hierarchies that organize migrations among islands in the Caribbean, always against the powerful backdrop of the United States. Sex tourism is recreated as a profitable industry that relaxes strict machista prejudices and allows for sexual experimentation of those who pay and some degree of social mobility of those whose bodies are for hire.

Martha Divine, Solange Graubel, and Sirena Selena, constantly negotiate their (sexual/gender) identities strategically so as to achieve higher levels of material agency in the context of patriarchal societies in the

\footnotetext{
${ }^{1}$ Mayra Santos-Febres, interview by Teresa Peña-Jordán, Centro Journal 15, no. 2 (Fall 2003): 125. Translation mine.
} 
Caribbean, where machismo employs double standards as regards social respectability versus enacted desires. Prevalent chauvinistic, capitalist and racist value paradigms influence these characters' performances of femininity, opening ways to manipulate material means in order to obtain more autonomy and a sense of agency on the one side; but also providing further possibilities for shame and humiliation (Martha of being read, Solange of losing Hugo, Sirena of falling in love). Santos-Febres' novel thus recreates the tension caused by bodies that incarnate a combination of alternative sexualities, histories and desires and therefore serve to complicate traditional feminine gender categories in a machista context while at the same time they continue to be forced to comply, to a great degree, to standardized ideals of wellbeing, emotional fulfilment and personal success.

The dominant narrative voice is that of Martha Divine, a middle-aged popular transvestite who rescues "Sirenito," a young mulatto prostitute, from the violent streets of San Juan the moment she hears his enchanting, melodious bolero voice, a commercial asset that Martha equates with the seductive/destructive power of the mythical sirens. Martha is set on success as an attractive, savvy and entertaining show-biz businesswoman. At the beginning of the novel she is described as "a real lady" (2). She is wonderfully put together, with "a portentous pair of silicon breasts and incredibly smooth skin in the cleft of the bosom." She is "tanned and long-legged; her nails [are] always painted garnet red, like the drop of coagulated blood on the tip of each of her fingers and toes." Her smile is "perfect, no nicotine stains, though she smoked incessantly" (2). Martha appears as "toda una señora," her impeccable ensemble the living image of mature feminine appeal. She is not only physically attractive, but also resourceful and ambitious, a model entrepreneur.

Martha's obsession with her perfect image resonates in Warren Kinston's observation that "many narcissistically vulnerable people lock themselves into defensive invulnerability," by committing themselves to a "shame-free (shameless) state of object narcissism." By doing so, the subject abandons the possibility of spontaneous interaction with social environments, adopting instead the posture of an object to be seen, acting only because of or for social conventions (Kinston 226). The middle-aged transvestite has adhered passionately to "The (feminine) Beauty Myth" prevalent in Western cultures, as described by Naomi Wolf: "a gaunt, yet fully breasted Caucasian, not often found in nature..." (2). Martha considers herself a powerful alchemist who can transform bodies in order to make them ready for commercial consumption in the active market of sexual tourism, reinforcing the status quo and the perpetuation of capitalism on the islands (Montes Garcés). In the same way as Wolf describes the rituals to which women subject themselves in order to approximate the ideal of physical perfection as having a religious value validated through stricts rites, Martha makes her solemn entrance before a show as "the master of illusions," powerful enough to concoct Sirena Selena, the irresistible bolero diva with "her case of bases, powders, disguising makeup, and magic" (Santos-Febres, Sirena Selena 31).

But although Martha, "master among masters" (31), appears to have the power to create enticing illusions with a box of creams, oils, and powders, she is nonetheless haunted by fears which Wolf recognizes in most "controlled, attractive, successful working women," a "secret 'underlife' poisoning our freedom: infused with notions of beauty, it is a dark vein of self-hatred, physical obsessions, terror of aging, and dread of lost control" (11). In the case of Martha Divine, these feminine fears are complicated even more by the terror of being exposed as not being a 'true' woman: "She trembled just thinking that someone, in the middle of takeoff, might point a finger at her and shout, "Look at that. That is not a woman"' (Santos-Febres, Sirena Selena 10). She has nightmares of being denounced as an impostor and being deprived of all her rights to the capitalist dream of a well-off existence that will allow her to escape the confines of Puerto Rico "...the comfort, the airborne luxury, the dream of traveling to other shores" (10). Martha has domesticated her body into a perfect performance of femininity, but the result is perhaps a too perfect one: "Not a single hair showed to betray her. Only her height and her voice and her very feminine mannerisms, too feminine, studiously feminine" (2).

The critic Ben Sifuentes-Jáuregui refers to transvestism as a performance of gender which, in many cases, is seen by outsiders as "representing the other," while for the "transvestitic subject" it in fact means "representing the Self," "becoming the Self," and "(re)creating the Self" (3). It is interesting to note here that Martha's performance of femininity is, as suggested by Sifuentes, an expression of who she really feels inside. Although well trained in the feminine rites of beauty, Martha feels that only the (trans-sex) operation in the U.S. will allow her to "rest in a single body." Only the chirurgical alteration of her body will allow her to "take off her clothes and see herself, finally, from the waist below the same as from above the waist, with tits and candy" (11). It can be argued, then, that Martha is not only a transvestite, but also a transsexual, since she is a person who feels trapped in a body that is not hers (Garber). Regardless of the label that is chosen to describe Martha's gender/sexual configuration, what remains clear is "her desire to represent normative 
gender difference seamlessly" (Sifuentes-Jáuregui 4). Martha operates socially following a hetenormative logic, for her, desire for men can only become intelligible being a woman (Kahman and Peres) and that is why her ultimate goal is to find a solvent husband and create the perfect heterosexual couple. Martha's narcissistic obsession with inhabiting a feminine body has led her to refine her skills at transforming herself into an object of desire for men, but also fuels her deepest fears of being shamed.

She torments herself with the possibility of letting a crack in her performance give her away and expose her to shame, embarrassment, and ridicule, as it happened to her transvestite friend: "They figured Maxine out as soon as she got off that 747 and put her through shame after shame in the customs office. Almost twenty hours they detained her, the guards making fun of her, dumping out the contents of her suitcases, breaking jars of makeup on the floor" (Santos-Febres, Sirena Selena 12). Critic Emilio Bejel suggests that "perhaps the transvestite dresses flamboyantly so as to make his/her body visible in the public space from which it has been displaced, rejected, or erased" (198). Martha Divine knows about rejection and shame from a young age, because when "his father, with the face of a vengeful archangel, poured gasoline on his dresses, he knew that the next thing burned would be him" (Santos-Febres, Sirena Selena 91). His decision as a young boy to follow his destiny and leave behind "that ugly, fat, hairy family who wore guayaberas, flowered rayon shirts, and polyester skirts..." (91) has not, however, kept him from the threat and the actual infliction of violence on his irreverent body. Life on the streets of San Juan has presented Martha with multiple ordeals which she is not ready to go through again: "I went through too many police raids to get these implants and the hormones that make me so fabulous" (91). The threat of gratuitous violence and humiliations seems to have accompanied Martha and her friends for most of their lives. Martha has worked very hard to overcome those humiliations by narcissistically focusing on re-inventing herself as an imposing businesswoman who knows how to make money and defend her interests. Even after Sirena Selena abandons her in Santo Domingo, Martha feels that at least "[s] he was arriving with a firm deal, a new business partner" (198). She is still a señora who retains a sense of control (ephemeral as it may be) over her destiny by "trafficking with bodies through the manipulation of desire" (Montes Garcés 190) in this transnational Caribbean context of sex tourism where consumers see sex as "more natural," and prostitution as not really that but "a way of life" 2 (O'Connell and Sanchez 43) protected, as in the Dominican Republic, by corrupt economic interests linked to Trujillism and the U.S (Arroyo).

The other señora in the novel is Solange Graubel, the wife of the rich Dominican businessman Sirena Selena eventually seduces. Solange is constantly reminding herself of her respectability, (high) social status, beauty, and power: "Now she has a house and forks and calla lilies and heirs. She has property in her name, has invested in jewels that she doesn't wear" (Santos-Febres, Sirena Selena 129). Solange seems to comply with the dictates of the "cult of True Womanhood" as described by critic Barbara Welter in 1966 in that, despite all her material possessions, she still remains "the hostage in the home" (151). Graubel's wife seems to adhere to traditional patriarchal ideals of femininity, as listed in Welter's article. Of the "four cardinal virtues" that Welter listed as expected of respectable women by nineteenth century's American society, "piety, purity, submissiveness and domesticity" (152), Solange clearly demonstrates the last two, virtues that her patriarchal Dominican society and Americanized elite request of her to be a true lady. She is fiercely devoted to her husband and her household, wanting her family and her home to reflect favorably on her. The maxim of the perfect home rings true for Solange and her fanatical dedication to organizing social events to the last detail. Solange has taken patriarchal principles related to women's domesticity as her creed: "Home was supposed to be a cheerful place, so that brothers, husbands and sons would not go elsewhere in search of a good time. Woman was expected to dispense comfort and cheer" (Santos-Febres, Sirena Selena 163). The perfectionist strike that characterizes many narcissistic dispositions is evident in the way she manages her domestic sphere, especially when outsiders are let into her home: "Everything must be perfect. Hugo will be happy, the guests pleased, the food exquisite." When planning a social event at her house "[t]he flowers must be impeccable...Not a single detail can escape [her], not a single detail" (73).

Solange needs to feel that "[e]veryone [is] falling over themselves with praise for me, that I took care of the most intricate details. Then Hugo will realize what he has at his side" (73). By using the verb "to have" to refer to her relationship with her husband, Solange gives away that she feels like another one of Hugo's possessions, like an object. She is obsessed by what people might think of her, measuring her self-value in the image other people have of her: "Espera, Solange, wait a second... Which of the guests has already seen you in that dress?" (73). In narcissistic fashion, she is excessively preoccupied and dominated by her image

\footnotetext{
${ }^{2}$ Julia O'Connell Davidson and Jacqueline Sanchez Taylor contend that sex tourism has less to do with the wish to engage in specific sexual practices and a lot more to do with the material enactment of control over one's and others' bodies.
} 
or status as object to other (Miller 88). She judges people harshly according to their appearances "that old harpy Angélica, such bad taste she has in clothing, always wearing gaudy colors...She never regained her shape after the ingeniero's last child" (Santos-Febres, Sirena Selena 71). However, she judges her own physical appearance as cruelly, too: "I really must lose some weight. Maybe I have time to call Yadia to give me a massage with algae on my thighs, and a wrap" (73). As a true dama (lady), Solange recognizes her dependency upon her husband, she knows very well that in machista Dominican society, "[y]ou need status at the top, and Hugo gives her status" (123). She has forged a privileged destiny for herself by accepting the role of the perfect wife to business magnate Hugo Graubel, "but the role had changed her. She had become a señora. And it fitted her marvelously, she couldn't deny it. Habit had converted her into Solange Graubel, wife of the millionaire businessman Hugo Graubel, mother of his two heirs, member of the board of directors of the National Library, patron of the arts. She really was una dama" (128).

Although Solange "knows very well where she is going, [s] he is going to the top and no one can move her from there" (129), the unsettling presence of the deliciously ambiguous Sirena/o Selena awakens all of her fears of being shamed once again. She knows that if Hugo succumbs to Sirena, the "scandal now, after so much work, would be the death of her prestige. It would turn her into the misfit she was before..." (135). Solange still has vivid memories of the shame and humiliation suffered as her paternal family's circumstances began to change for the worse. As a young girl, she

decided to grow up slowly, to keep up appearances with her mother, who began little by little to sell the furniture and took her youngest daughter out of the exclusive girls' school where she was studying. Solange was deathly afraid of her alcohólico father, who presented her so cordially to people to whom he owed money, to his business associates. Solange felt as if he were trying to sell her. She could still see those business associates looking at them disdainfully -at her, at her father...She grew slowly because of the shame. (129)

Solange has been able to create a social persona that embodies the ultimate rich Dominican lady. But deep inside, her narcissistic perfectionism hides all her shame wounds, which the young transvestite singer Selena is able to see right away: "Oh, yes, Solange, I know. You're a climber, like me, a young girl dressed like a woman, who believes in reaching the top. And you suffer, you are rich but you suffer, there are memories embedded in your soul that you can't shake" (133). Selena sings so beautifully and so sadly that Solange has to run to express her frustrated envy and desperation in the privacy of her room: " Cálmate, Solange, take a deep breath, don't be ridiculous. What are the guests going to think if they don't see you at the party; the help..." (170-1). Solange needs to hide the flood of emotions Selena's singing has awakened. She cannot lose face before a young transvestite who pretends to play the diva, restraint and modesty are, after all, two other crucial attributes of a true lady (Welter). So as to sustain her public image as the beautiful influential wife of a successful Dominican, Solange is less worried about her husband becoming emotionally involved with Sirena and more about their affair going public and threatening all that she has so laboriously constructed by renouncing her autonomy and becoming a rich man's prized possession.

Martha Divine and Solange Graubel have internalized what John Berger describes as the way in which a woman has traditionally viewed herself in patriarchal societies: "From earliest childhood she has been taught and persuaded to survey herself continually... She has to survey everything she is and everything she does because how she appears to others and ultimately how she appears to men, is of crucial importance for what is normally thought of as the success of her life" (Berger 46-7). Both characters react against past shame by narcissistically focusing on their image as impeccable ladies who need to irradiate glamour and control at all times, reinforcing rather than upsetting established chauvinistic and materialist values on the islands.

Sirena Selena employs a different tactic; rather than focusing on creating an image of respectable femininity, this talented mulatto prefers to concentrate on creating the illusion of an irresistible siren ${ }^{3}$ whose sexual and racial ambiguity, physical beauty, and amazing voice can seduce men (and women) into adoration:

When Sirena passed through the door of her room, at exactly fifteen to six, she was the living image of a goddess. Each step, carefully considered, evinced the aura of a consummate bolerista.

\footnotetext{
${ }^{3}$ The word "sirena" in Spanish translates into "mermaid" in English. Santos-Febres plays with both senses of the term "siren," since Sirena Selena is as much a man-eater, as -referring to the myth- an incredible singer that enchants men into surrender.
} 
She was seductive, serene, with head crowned with perfect black curls and her face framed by two curls that fell to the middle of her cheeks. From each ear hung a spray of oval pearls surrounded by diamonds. Her slender form was sheathed in sparkling mother-of-pearl, from which a tanned, perfectly sculpted leg emerged with each step, as if from the sea at sunset. (Santos-Febres, Sirena Selena 34-35)

Sirena has learned to use her beautiful voice to her advantage, and her ambition will take her far, because all you need is "[a] little talent and a lot of businesswoman's instinct. Sirena bets she has more than enough of both ingredients" (30). Sirena's narcissism claims all her attention on herself, and for that reason, for Sirena "no one had ever really existed outside of her world, even if their paths crossed" (50). Imagining a future of success and material abundance in show-biz, her ambition is to be able to immigrate to New York, "[t]o try his luck there as who he really is" (30). Sirena asks her santos ${ }^{4}$ that "my voice come out filled with needles, dense, that it enter the breasts of those who listen to me and wring longing and applause from them," so that it can allow her "to have power and dominion to conquer [her] enemies" (7). Replicating the mythical sea creatures who destroyed as they seduced, Sirena wants to use boleros to disarm those who used to hurt him when he was "the most fragile of all the hustlers on the street, the most screwed-up fifteen-year-old in the whole barrio" (8) those

grown men who from a distance somehow realized something that I only felt vaguely. They came and opened their car doors already knowing that I would get in, I would sit there staring coldly at them, I would let the trembling hand go wherever it went, knowing that what always happened would happen, the swelling, the delicious fear, the urge to cry, the burning saliva, the tear in my eye, the yearning to die right there... Then came the hardening of their faces, after discovering, but not saying, what they have discovered. (8)

Sirena/Sirenito accuses the men who paid "twenty pesos" for his sexual favors of awakening his homosexual desire as a young boy, and of later despising him and themselves for their shared desire. They were his "worst enemies" because they "disappeared afterward, as if swallowed up by the earth" (9), leaving Sirenito on his own, trying to escape Social Services and the menace of a state orphanage, a place where he was definitely not going. Intent on avoiding being locked up, he stays in the streets, but they prove too dangerous and he becomes a victim to violent rape. From then on, Sireno progressively becomes "la Sirena" and the rumors spread of his/her power over men:

It was rumored that even when he was a kept boy no one had been able to hang on to him, that at the precise moment when one penetrated him, melodies escaped from his chest and he began to croon with his ecstatic and glorious voice full of the Spirit of Light. They said that even the most macho men wilted in his presence, and that later he would gently turn them, wet them with ceremonial saliva, and enter their hot, waiting bodies. (46-47)

Sirenito then becomes Sirena Selena and "to seduce men she makes use of her 'feminine weapons,' particularly her voice, which she uses as a means of protection and defense against penetration" (González-Allende 58), Sirena creates a performance that aims to fight desperately the shameful memories of rape, misery, and addiction. Her enchanting songs acquire, then, three functions: "to overcome pain through an objectification process, to avoid being penetrated, and to cast a spell on men and subdue them through penetration" (58). Even if, as González suggests, Santos-Febres' novel does not question patriarchal values that place a stigma on those who are penetrated while granting power to those who are able to penetrate, the author effectively destabilizes assumptions of "masculinity" or "phallic" power based on appearances. Both Sirena and Leocadio-the Dominican character who mirrors many characteristics of magical Selena-have beautiful and rather fragile bodies which awaken male desire everywhere they go because "[a] hungry eye always spots them" (Santos-Febres, Sirena Selena 210). These bodies, though, hide surprises, as the avid Martha Divine confesses to herself when helping Sirena get ready for the show: "Sirena's penis was immense, a little grotesque because it was so disproportionate to the rest of her body" (34). Sirena Selena seduces from the dangerous limits of sexual ambiguity: "Her hairless body, seminude, in a tiny bikini, made her look like

\footnotetext{
4 "Santos" like "María Piedra de Imán" are deities in the pantheon of "Santería," a syncretic religion originated in the Caribbean as a fusion of Christianity (more specifically, the Catholic Church) with African (Yoruba) beliefs.
} 
a tomboy trying to be un hombrecito on the beach, but showing her femme side with her little jumps and squeals among the trash" (43). Sirena Selena brings her "secret" to her music, thus subverting bolero, a traditional musical genre that sings the conflicts of heterosexual love. By doing this so effectively, her character "questions the fallacy of absolutes and established identities" (Cuadra 157, translation mine) although the limits to this questioning rest in Sirena's ambiguous looks, not only her delicate figure but also her rather light mulatto skin.

Sirena, as well as Leocadio, the Dominican boy who acts as his double and his successor, have caramelcoloured skin that marks them socially, particularly as desirable objects, but is also associated with racial passing strategies (Arroyo). Strong racial prejudices on the islands are materialized in the laborious make-up process that turns Sirena into such a potent source of seduction, which begins with a striking red base that Martha applies onto her mulatto skin before finishing with a (light) "skin colour base." Sirena and Martha -both marginalized in their country- still retain a superior racial status as Puerto Ricans and comment on the fact that they did not know about Dominican millionaires and such luxurious hotels in Santo Domingo, given that the image of Dominicans in Puerto Rico is limited to their status as "black, dirty and poor." The novel thus effectively recreates racial and economic hierarchies of prejudices that stimulate inter-island migrations, where Puerto Rico appears as the economic and legal bridge to the idealized U.S., a problematic myth, since there, both Dominicans and Puerto Ricans are still to a good extent second-class citizens.

Sirena's narcissistic focus, thus, subjects her to the role of object of desire, limiting her agency as subject and restricting her desire to "the desire to be desired." This symbolic violence perpetrated by patriarchal violence, according to Celis, effectively makes feminine appearance "[young women's] sexual organ and the strongest pillar of their narcissism" (95, translation mine). This narcissistic reduction of the subject to the status of object-even if an economically valuable one--effectively isolates Sirena because, according to specialists, "in pathological narcissism one's own ego is the more or less exclusive love object, and consequently, there is an impaired capacity for object love" (Broucek 52). For love and care to flourish, as Broucek discusses, the ego has to be able to recognize others as subjects "in their own right," and not simply tools to be used "in an exploitive way in the service of one's own self-aggrandizement" (53). At the end of the novel, Sirena wonders about her relationship with Hugo Graubel and tries to explain her feelings as pure economic interest: "I love the luxury that surrounds him, his wallet that is always full of billetes, I love their smell, and the path they open for me, with me sitting in the driver's seat and the billetes taking me to the very heights of paradise" (Santos-Febres, Sirena Selena 189). Although her ambition and desire for economical agency and autonomy are undeniable, Sirena is very afraid of deeper emotional attachments such as the one she is beginning to feel towards Hugo. She cannot let love happen because that can mean dependency and that is why she needs to "protect herself" by escaping with as much as possible:

The next day, Hugo Graubel awakens, tired. He searches in the bed for Selena's body. She's not there. Maybe she's in the bathroom. He gets up. He goes to see what time it is. He can't find his Cartier watch. He looks for his trousers, his wallet in the pocket. It's not there either. He goes to the closet. Empty hangers; the boxes from the shoes he bought Sirena are also empty... "And she didn't leave anything else, not even a note for me?" "Not that I know of, Señor Graubel." (207)

Sirena leaves Hugo and Martha Divine behind, in her search for the applause and recognition that are legitimately hers because she is "ready to identify the luxury that will accompany her from now on" (47). Martha Divine, Sirena's agent and creator, cannot blame her disciple because “...life isn't life for one who lives with this weight in her belly...That's why she doesn't blame Sirena. How could she blame her?" (47)

Santos-Febres' novel recreates a map of close islands which share prejudices and values and where colonial histories crystallize in economic and social hierarchies that organize the islands very clearly. As the tiguerito $^{5}$ Migueles explains to Leocadio: "As soon as I save up enough for my ticket, I'm heading for Puerto Rico. That is where the real money is, man;" Puerto Ricans are "used to being gringos," and "everybody does drugs" (Santos-Febres, Sirena Selena 157). Haitians, Migueles explains, don't count because: "How could they count, if sometimes even the in the poor barrio where he lived nobody wanted to rent them rooms. Haitians lived like stray dogs" (157). Martha Divine knows very well that even though in Puerto Rico federal laws prohibit underage Selena to work for wages, in the Dominican Republic "they don't care about such things" (5).

\footnotetext{
${ }^{5}$ Chris Girman investigates the figure of the Dominican "tíguere," a macho figure of physical dominance and control who, as a "sex worker ends up looking like the ultimate tíguere. He is able to earn a living by using one of the only pieces of capital he owns- his own body" (153)
} 
Sirena herself has her own preconceptions about the Dominican Republic crashed because "On the news they only talked about Dominicans fleeing in boats -encrusted with salt, or gnawed at by sharks and floating belly up in the Mona passage" (84). National and social stereotypes inform migrations among the islands and money, "the dollar," appears as the ultimate tool towards more autonomy.

These "marginal migrations" (Puri 4) follow in many cases the pattern of the very profitable industry of sex tourism, a capitalist configuration that still "supports powerful racist ideologies and stereotypes created in predominantly white societies about the innate sensuousness of black bodies" (Aymer 209). Martha the businesswoman knows this well:

The wealthy tourist's urges must be satisfied. Folkloric dancing and meringue orchestras will never be able to seduce them so deliciously. Variety, gentlemen, variety. That's what the public wants. In their own countries, even drunk, they wouldn't go to a show of locas, but once they're lost in salty arrumacos of a Caribbean island, rum in their veins, skin scorched by unfamiliar temperatures, any novel idea would invite them to relax their prejudices. (Santos-Febres, Sirena Selena 93-94)

Benigno Sánchez-Eppler and Cindy Patton, in the introduction to their book Queer Diasporas (2000) affirm that "sexuality is on the move" (2). The strategies used by Martha Divine, Sirena Selena, Solange, Migueles, and Leocadio, among others in the novel, reflect Sánchez and Patton's conviction that

identity is viewed as strategic, rather than essential, contingent on, reproduced, decaying, co-opted, in relation to material and discursive factors that, especially in the context of sexualities, are always a complex lamination of local onto global onto local. Sexuality is intimately and immediately felt, but publicly and internationally described and mediated." (2)

The three characters analyzed, Martha Divine, Solange Graubel, and Sirena Selena, constantly negotiate their (sexual/gender) identities strategically so as to achieve higher levels of material agency in the context of patriarchal societies in the Caribbean, where capitalist economies place added value on their well-trimmed bodies. The three characters exhibit the dialectic tension that characterizes the connection between shame and narcissism: "grandiosity and desire for perfection," on the one side, "and the archaic sense of self as flawed, inadequate, and inferior following realization of separateness from, and dependence on, objects" on the other (Morrison 66). Their early experiences with shame start a cycle where "shame and narcissism inform each other, as the self is experienced, first, alone, separate, and small, and, again, grandiosely, striving to be perfect and reunited with its ideal" (66). These ideals, however, cannot escape being constructed under the prevalent Caribbean paradigms of chauvinism, capitalism and racism, and these characters, as the author herself has explained, do not achieve any "liberation" in their determinate search for self-determination; but rather, engage in constant "negotiations" (Santos-Febres, Interview 121) that aim purely and simply at survival.

\section{Competing Interests}

The author has no competing interests to declare.

\section{References}

Arroyo, Jossianna. "Sirena canta boleros: travestismo y sujetos transcaribeños en Sirena Selena vestida de pena." Centro Journal. 15.2 (2003): 38-51.

Aymer, Paula. "Exposing Caribbean Tourism." Small Axe. 6.2 (2002): 209-211. DOI: https://doi. org/10.1215/-6-2-209

Bejel, Emilio. Gay Cuban Nation. Chicago: U of Chicago P, 2001.

Berger, John. Ways of Seeing. New York: Penguin, 1977.

Broucek, Francis J. Shame and the Self. New York: The Guilford Press, 1991.

Celis, Nadia V. "La Traición de la Belleza: Cuerpos, Deseo y Subjetividad Femenina en Fanny Buitrago y Mayra Santos-Febres." Chasqui: revista de literatura latinoamericana. 37.2 (2008): 88-105.

Cuadra, Ivonne. "¿Quién canta? Bolero y ambigüedad genérica en Sirena Selena vestida de Pena." Revista de estudios hispánicos. 30.1 (2003): 153-63.

Garber, Marjorie. Vested Interests: Cross-Dressing and Cultural Anxiety. NY: Routledge, 1992.

Girman, Chris. Mucho Macho: Seduction, Desire, and the Homoerotic Lives of Latin Men. Binghamton, NY: Harrington Park Press, 2004. 
González-Allende, Iker. "De la pasividad al poder sexual yeconómico: El sujeto activo en Sirena Selena," Chasqui: Revista de Literatura Latinoamericana. 34.1 (2005): 51-64. DOI: https://doi.org/10.2307/29741919

Kinston, Warren. "The Shame of Narcissim." The Many Faces of Shame, edited by Donald Nathanson. New York: Guilford Press, 1987, pp. 214-245.

Miller, Susan B. Shame in Context. Hillsdale, NJ: Analytic Press, 1996.

Montes Garcés, Elizabeth. "Cuerpo, deseo y lenguaje en La Celestina y Sirena Selena vestida de pena." Revista Canadiense de Estudios Hispánicos. 32.1 (2007): 189-202.

Morrison, Andrew. Shame: The Underside of Narcissism. Hillsdale, NJ: The Analytic Press, 1989.

O'Connell Davidson, Julia and Jacqueline Sanchez Taylor. "Fantasy Islands: Exploring the Demand for Sex Tourism." Sun, Sex, and Gold: Tourism and Sex Work in the Caribbean, edited by Kamala Kempadoo. Rowman \& Littlefield: Maryland, 1999, pp. 37-54.

Patton, Cindy and Beningno Sánchez-Eppler. Introduction. Queer Diasporas. Ed. Cinty Patton and Benigno Sánchez-Eppler. Durham: Duke UP, 2000. 1-14.

Peres Alós, Anselmo and Andrea Cristiane Kahmann. "La ruptura con el continuum sexo-género-deseo: algunos apuntes acerca de la obra Sirena Selena vestida de pena, de Mayra Santos-Febres." Espéculo: Revista de Estudios Literarios 29 (May-June 2005). Accessed January 15, 2015. http://www.ucm. es.libproxy.lib.unc.edu/info/especulo/numero29/sirena.html.

Puri, Shalini, ed. Marginal Migrations: The Circulation of Cultures within the Caribbean. Oxford: Macmillan Caribbean, 2003.

Santos-Febres, Mayra. Sirena Selena. Translated by Stephen Lytle. New York: Picador, 2000.

--.. Santos-Febres, Mayra. Interview. Centro Journal. By Teresa Peña-Jordán. 15.2 (2003): 117-125.

Sifuentes-Jáuregui, Ben. Transvestism, Masculinity, and Latin America Literature: Genders Share Flesh. New York: Palgrave, 2002. DOI: https://doi.org/10.1057/9780230107281

Welter, Barbra. "The Cult of True Womanhood: 1820-1860." American Quarterly. 18.2 (1966): 151-174. DOI: https://doi.org/10.2307/2711179

Wolf, Naomi. The Beauty Myth. New York: Perennial, 2002.

How to cite this article: Bortolotto, MC 2020 Perfect Performance for export: shame, narcissism and contaminated ideals in Santos-Febres' Sirena Selena (2000). Anthurium, 16(2): 7, 1-8. DOI: https://doi.org/10.33596/anth.424

Published: 21 December 2020

Copyright: (c) 2020 The Author(s). This is an open-access article distributed under the terms of the Creative Commons Attribution 4.0 International License (CC-BY 4.0), which permits unrestricted use, distribution, and reproduction in any medium, provided the original author and source are credited. See http://creativecommons.org/licenses/by/4.0/. 